\title{
Letter to President Lyndon Johnson
}

\author{
April 13, 1967
}

Never content to remain silent in the face of injustice, Beerman penned a letter to President Lyndon B. Johnson in 1967, as he would on subsequent occasions. Here he implored the president to avoid using his recently submitted tax payment for the Vietnam War. Instead, he recommended to the president that he use tax revenues to pursue peace-loving activities.

Dear Mr. President:

Mrs. Beerman and I have just paid our income tax for the year 1966. That portion of our tax which helps to sustain the war in Vietnam has been paid involuntarily. We have no wish to support what we consider to be unjust. We should be happy to pay even a greater proportion of our income for works of healing and peace, but the acts of violence being perpetrated by our government violate our conscience. That portion of our tax that helps make these acts possible we pay under protest.

Our hearts reach out to you and to all who must face the terror of decision. We pray always that the courage of compassion and conciliation may come to those who guide and serve both our country and those who oppose it.

Sincerely,

Leonard I. Beerman

\section{COMMENTARY BY JUDITH VIORST}

The second half of the sixties was a time of accelerating political turmoil as objection to US involvement in Vietnam expressed itself in a widening range of private and public protests: massive demonstrations, teach-ins, the burning of draft cards, 


\section{April 1967}

Dear Mr. President:

Mrs. Beernow and I have juirt paid our income tanx for the year Ique. That portion of om tax which helbs to sustain the war in Vietran has been paid involuntanly. Wo have no wish to subbort What un considen to be ungurust. We should be haply to pay even a greater proportion of our micome fur works of healing and beace, but the acto of violence being buectrated by ous qovernment violete oun conscience. That portion of an tax that helps mave these acts porsible we paip undes protest.

oun hearts read out to you and to all who noust fores the tener of dacsions. We pray always that the comage of compassicon and conculiation may come to those soto grich and sewe both on countiny and thos who ophore of. Sincenly. 
the occupying of university buildings, pamphlets, and petitions and letters like Leonard's from women and men opposed to the use of their taxes to fund this war.

As a mother of young children living in Washington, DC, I joined Another Mother for Peace and Women Strike for Peace, spending many weekends marching my kids around the White House, chanting, "What do you want? Peace. When do you want it? Now." (On other weekends we picketed to the chant "What do you want? Freedom," while I explained to my sons that no, this wasn't a mistake-we were doing civil rights, not peace, today.)

The women I marched with back then made an effort to always be "properly" dressed, intending to make the point that even very middle-class, very "proper" Americans were passionately against this unjust war. Like Leonard and the decorous tone he strikes in his oppositional but law-abiding letter, we wished to set a tone of respectful rebellion.

By the early 1970s, however, even we proper ladies needed to up our game in protesting the war, joining a sit-in in the halls of Congress and going-briefly-to jail. And Leonard, in the years since his 1967 letter, vastly expanded the realm of rabbinical proprieties, showing us in a lifetime of courageous words and deeds what can and must be done in the face of injustice. 